\title{
English Extensive Reading Material Needs in Digital Era
}

\author{
Nurul Lailatul Khusniyah ${ }^{1}$ \\ DOI: $10.35445 /$ alishlah.v13i1. 560
}

\section{Article Info \\ Keywords: \\ Digital Era \\ English \\ Material \\ Reading}

Kata kunci:

Era Digital

Bahasa Inggris

Bahan Ajar

Membaca

\begin{abstract}
Teaching material is the primary need for the teaching and learning process. Advanced technology has influenced the paradigm of material presenting. This study was to identify material needs for English extensive reading courses in the digital era. The study used a qualitative approach through the descriptive qualitative method. Data is taken from observation, interview, and questionnaire. Data validity used triangulation, and analysis data used data reduction, data display, and taking conclusion. The result of findings shows that the need of teaching materials for learning extensive reading in English must be in line with the curriculum so that students can answer global challenges, the industry, technological developments, and changes in human life that continue to develop. The presentation of the material is also directed at implementing digital facilities that are easily accessible by students. The study results also have implications for exploring the ability to read digital sources and material variations according to student needs or globalization competition.
\end{abstract}

\begin{abstract}
Abstrak
Materi ajar menjadi kebutuhan utama dalam proses pembelajaran dan pengajaran. Paradigma penyajian materi ajar di kelas dipengaruhi oleh kemajuan teknologi. Penelitian ini bertujuan untuk mengidentifikasi kebutuhan materi ajar untuk pembelajaran membaca ekstensif bahasa Inggris di era digital. Penelitian ini menggunakan pendekatan kualitatif. Data diambil melalui observasi, wawancara dan kuesioner. Validasi data menggunakan triangulasi dan teknik analisis data terdiri dari tahap reduksi data, penyajian data dan penarikan simpulan. Hasil temuan menyimpulkan bahwa kebutuhan materi ajar untuk pembelajaran membaca ekstensif bahasa Inggris harus sesuai dengan kurikulum agar mahasiswa mampu menjawab tantangan global, dunia industri, perkembangan teknologi, dan perubahan kehidupan manusia yang terus berkembang. Materi ajar juga diarahkan pada implementasi fasilitas digital yang mudah diakses oleh mahasiswa. Hasil penelitian juga berimplikasi pada ekplorasi kemampuan membaca sumber digital dan variasi materi yang sesuai kebutuhan mahasiswa ataupun persaingan globalisasi.
\end{abstract}

\footnotetext{
${ }^{1}$ Pendidikan Bahasa Inggris UIN Mataram, Indonesia

Email: nurullaila@uinmataram.ac.id
} 


\section{INTRODUCTION}

The development of technology has provided enormous changes to the learning and teaching process in the classroom (Szymkowiak, Melović, Dabić, Jeganathan, \& Kundi, 2021). Especially in the Covid-19 pandemic era, technological advances have helped to learn activities run efficiently, and learning objectives can be achieved according to the predetermined curriculum. Learning activities that change from face-to-face to online demand a quality learning activity (Daumiller et al., 2021). In addition, the provision of teaching materials is also more accessible, and students can access teaching materials through various applications or technology devices. Thus, teachers must understand the needs of teaching materials by the global challenges of technological advances so that they can meet the needs of students in order they become qualified graduates in facing the challenges of global competition. Teachers are required to integrate technology in the classroom (Uerz, Volman, \& Kral, 2018) which is presented in teaching materials.

Teaching materials have a significant role in the learning process, such as in the English Extensive Reading course at UIN Mataram. This course aims to improve reading skills by reading many books that students have to present and building students' awareness of reading and habits (Iftanti \& Shofiya, 2018). However, in the era of the Covid-19 pandemic, there are many challenges in providing various authentic teaching materials that suit students' needs or current conditions (Guo, 2012).

The results of student background analysis and student learning activities during the 20192020 odd semester conclude that students rarely use printed books in class or used them in presenting extensive reading performance. In addition, the results of the interviews also showed that students prefer to find learning materials through technological devices such as smartphones. Also, the current concept of literacy has shifted to digital literacy (Shariman, Razak, \& Noor, 2012). Reading competence has the primary role in 21 century that help everyone to face the future challenge (Alexander et al., 2012). Everyone has a different competence (Duncan, Mcgeown, Griffiths, Stothard, \& Dobai, 2016).

Therefore, the need for teaching materials in the Extensive Reading course needs to be tailored to the needs of students and by the current digital era (Pop, 2015). Digital authentic material can encourage a better learning process and better student achievement (Purwaningrum \& Yusuf, 2020), such as contextual internet-based instructional material (Manurung, 2015). Also, technology has motivated students to read some books online or in print (Loh \& Sun, 2019). Advances in technology have also built creativity in creating E-reader applications that can be used in classrooms for students (Hashim \& Vongkulluksn, 2018). However, E-reader needs a high cost if the teachers want to apply it in the class. Even teachers still have to make extensive reading teaching materials relevant to the digital era and make students active readers (Wahyuningsih, 2018).

Thus, this research is aimed at the concept of teaching material needs that are relevant to the digital era by paying attention to the components of the time and place of reading, the physical structure of the text, and the way other people in the social context related to the text (Evans, 2017). Student experiences present these components. This is because digital reading technology has changed the behaviour, values, and thoughts regarding reading time as a form of pleasure in everyday life (Hupfeld, Sellen, O'Hara, \& Rodden, 2013). Therefore, this study is different from previous research related to teaching materials for reading learning. The concept of the study is based on the development of the student's learning environment and the development of human life, as well as the need for an educational process that can balance global needs. Teaching materials as an element in achieving educational goals are essential to be developed. This is the main reason for conducting this research.

This research is expected to make a real contribution to the teachers that teaching materials must be tailored to the needs of students and the development of human life, both science and technology. This means that the teaching materials in the classroom must be authentic according to 
the times and changing life. Moreover, reading is one of the competencies that plays an essential role in facing global challenges.

\section{METHODS}

The research used a qualitative approach through a descriptive qualitative method. It explored the phenomenon of the problem of English extensive reading material for students in a digital era. The data is collected using a questionnaire that is distributed to students in the Extensive Reading Subject. The study identified students' responses or comments in the questionnaire. Then, it is categorized and analyzed. The result of data analysis presented using percentage frequencies. In contrast, observation and interview were used in the preliminary study to identify a problem. The questionnaire was designed to refer to the Nunan theory (Tomlinson, 2013), and it combined with the role of extensive reading learning (Ghanbari \& Marzban, 2014). The questionnaire will assess using the Likert scale.

\begin{tabular}{|c|c|c|}
\hline Components of material & Role of Extensive Reading in Class & Number \\
\hline $\begin{array}{l}\text { Material related to the current } \\
\text { curriculum }\end{array}$ & $\begin{array}{l}\text { Input material is relevant with the program } \\
\text { study curriculum in university }\end{array}$ & 1,2 \\
\hline $\begin{array}{l}\text { Material is authentic and related to the } \\
\text { advanced in technology }\end{array}$ & $\begin{array}{l}\text { 1. It increases the vocabulary from the } \\
\text { context text } \\
\text { 2. It can consolidate previously learned } \\
\text { the language } \\
\text { 3. It encourages exploitation of textual } \\
\text { redundancy }\end{array}$ & $3,4,5$ \\
\hline $\begin{array}{l}\text { It builds the interactive process between } \\
\text { text and students }\end{array}$ & $\begin{array}{l}\text { 1. It increases students' exposure to } \\
\text { language } \\
\text { 2. It helps build trust with extended text }\end{array}$ & $6,7,8$ \\
\hline Focusing on the formal language aspect & $\begin{array}{l}\text { It can improve the general language } \\
\text { competence of students }\end{array}$ & 9,10 \\
\hline It supports students' ability to learn & It motivates students to read & 11,12 \\
\hline $\begin{array}{l}\text { Students can implement their ability out } \\
\text { of class }\end{array}$ & $\begin{array}{l}\text { 1. It can improve other English students' } \\
\text { skills } \\
\text { 2. It facilitates the development of } \\
\text { predictive skills }\end{array}$ & $13,14,15$ \\
\hline
\end{tabular}

The study participants are the third-semester students in the 2019-2020 academic years, 90 students. They are taken from 3 classes of Extensive Reading Course. The sample is taken using randomly. The analysis data used the Miles and Huberman concept (Miles \& Huberman, 1994). There are three steps, including 1) data reduction is the process of identifying the problem and collecting data, 2) display data is presented data as a category and analysis of data, and 3) taking conclusion. The data validation process was done through triangulation analysis.

\section{FINDINGS AND DISCUSSION}

The questionnaire data analyzed show that the need for English extensive reading materials in the digital era must be linked to technological developments the industrial and global challenges. It means that the material studied by students can be used in the industry, which has developed very rapidly in line with changes in human life that continue to advance. Teaching materials can also be presented and accessed easily using technology devices. The following is the percentage and average value of the questionnaire data that has been processed. This data describes the results of the analysis of the needs for English Extensive Reading Materials;

Table 1. English Extensive Reading Material Needs

\begin{tabular}{llcc}
\hline Number & \multicolumn{1}{c}{ Items } & \% & Average \\
\hline 1 & $\begin{array}{l}\text { Extensive reading material related to the goals of learning from university } \\
\text { and program study curriculum }\end{array}$ & 100 & 4.8 \\
2 & Extensive reading material must be relevant to the national curriculum & 80 & 3.9
\end{tabular}


Al- Ishlah: Jurnal Pendidikan, June 2021, 13 (1), Pages 763-768

Nurul Lailatul Khusniyah

$3 \quad$ Extensive reading material build the students' comprehending toward vocabulary meaning both literal or contextual

$4 \quad$ Extensive reading material can make students associate text with previous learning experiences and knowledge various learning sources by utilizing technological devices

6

7 Students can explain the contents of the text literally, and others can understand the context and explanation

Students have confidence in explaining the text or reading sources that have been read

Extensive reading material make students able to dissect the text more deeply with their level of confidence and experience

Extensive reading material can improve students' understanding of aspects of formal language related to text

Extensive reading material make students able to identify formal grammar well in the text Reading text increases the enthusiasm of students in reading Varied reading texts in various scientific fields build students' high interest in reading Reading text used in class can improve other language skills Reading text is able to facilitate students' reading needs The material can develop reading skills that can be applied in students' daily lives

The table data illustrates that the level of need for English Extensive Reading Materials. Each percentage and average value that has been described the level of need for learning materials. The need for extensive reading materials must build a series of activities that guide teachers and students through learning pathways at the right level of difficulty and involve both motivation and practical goals. The material must contain many things that teachers usually do as part of their teaching, namely: stimulating student interest, reminding them in advance about learning, telling them what they will learn later, explaining the content of new material, connecting ideas with student learning previously, it takes students to think of new material, helps them to get feedback on learning, encourages them to practice, ensures what they know, allows them to correct their learning progress, and helps them do better in learning.

In addition, the findings indicate that the material needs for students related to the level of understanding of knowledge, among others (Clarke, Truelove, Hulme, \& Snowling, 2014);

1. The linguistic level where the reader manages and processes the word itself and its meaning.

2. Microstructure level where the reader isolates words to manage and process the more significant meaning of the text.

3. Macrostructure level where the reader manages and processes theme, topic, and genre information about the text.

Therefore, teachers can present material in videos, DVDs, e-mails, Youtube, dictionaries, grammar books, readers, notebooks, or exercises. In addition, the material can be drawn from newspapers, photography, native speakers, teacher instructions, practice on cards, or discussions between students. Moreover, advances in digital technology provide easy access for everyone in presenting teaching materials. Teachers have a bigger challenge in preparing extensive reading teaching materials in the digital era because the material provided can stimulate students to build digital reading habits (Sun, Loh, \& Nie, 2021; Johnsson-Smaragdi \& Jönsson, 2006). In current conditions, teaching materials must be presented with a digital model (Larson, 2012).

Thus, extensive reading material can answer challenges in the learning and teaching process because reading ability is a complex social phenomenon. Essentially reading is a process to achieve success in social life. Reading is understanding the meaning in the text and understanding the phenomena of social life in society. It means that the material designed by the teacher can facilitate 
the needs of this phenomenon. As has been found, activities in extensive reading learning lead to understanding the content of reading related to how a person understands the context and has experienced it. In addition, the data findings indicate that students have a lot of knowledge about the themes in reading that can be used in developing reading interest.

From the findings, it is known that teaching materials must be designed according to students' needs, which are related to current global conditions. It means learning objectives from teaching materials that are designed to be relevant to the curriculum in the study program. In extensive reading courses, students have to build vocabulary from printed books or texts that are read literally and in context. Thus, the materials that students learn can relate to the experience and knowledge that they have previously. The design of materials must also direct students to use various learning resources through technological devices. This, of course, can provide a different experience in understanding the content of the text. Students can also study various variations of texts from various sciences

\section{CONCLUSION}

The findings concluded that students needed extensive reading learning teaching materials that were by the current curriculum development and the objectives of the educational process in the English education study program. Teaching materials presented to students must follow science (authentic) and technology used to facilitate learning activities. The reading texts given to students must meet both the language aspect and the text content related to the learning experience and student knowledge. In addition, teaching materials must also build enthusiasm and confidence in students in understanding the context of reading texts from various sources. These findings have implications for the development of teaching material models that can meet the needs of students, graduates who want to be created by universities, and the development of human life that continues to develop. However, research is still limited to identifying the need for extensive reading materials. Therefore, research results can still be developed to identify the need for extensive reading materials related to the technology or global needs in the industry because reading skills are fundamental in real life. This ability is useful for graduates in understanding situations that occur both literally and in context.

\section{REFERENCES}

Alexander, P. A., Fox, E., Maggioni, L., Loughlin, S. M., Baggetta, P., Dinsmore, D. L., ... Dumas, D. (2012). Reading Into the Future: Competence for the 21st Century. Educational Psychologist, 47(4), 259-280. https://doi.org/10.1080/00461520.2012.722511

Clarke, P. J., Truelove, E., Hulme, C., \& Snowling, M. J. (2014). Developing Reading Comprehension. West Sussex: John Wiley \& Sons Ltd.

Daumiller, M., Rinas, R., Hein, J., Janke, S., Dickhäuser, O., \& Dresel, M. (2021). Shifting from faceto-face to online teaching during COVID-19: The role of university faculty achievement goals for attitudes towards this sudden change, and their relevance for burnout/engagement and student evaluations of teaching quality. Computers in Human Behavior, 118. https://doi.org/10.1016/j.chb.2020.106677

Duncan, L. G., Mcgeown, S. P., Griffiths, Y. M., Stothard, S. E., \& Dobai, A. (2016). Adolescent reading skill and engagement with digital and traditional literacies as predictors of reading comprehension. British Journal of Psychology, 107(2), 209-238. https://doi.org/10.1111/bjop.12134

Evans, E. (2017). Learning From High School Students' Lived Experiences of Reading E-Books and Printed Books. Journal of Adolescent and Adult Literacy, 61(3), 311-318. https://doi.org/10.1002/jaal.685

Ghanbari, M., \& Marzban, A. (2014). Effect of Extensive Reading on Incidental Vocabulary Retention. Procedia - Social and Behavioral Sciences, 116, 3854-3858. https://doi.org/10.1016/J.SBSPRO.2014.01.854

Guo, S. cing. (2012). Using authentic materials for extensive reading to promote English proficiency. English Language Teaching, 5(8), 196-206. https://doi.org/10.5539/elt.v5n8p196 
Hashim, A. K., \& Vongkulluksn, V. W. (2018). E-Reader apps and reading engagement: A descriptive case study. Computers and Education, 125, 358-375. https://doi.org/10.1016/j.compedu.2018.06.021

Hupfeld, A., Sellen, A., O’Hara, K., \& Rodden, T. (2013). Leisure-based reading and the place of ebooks in everyday life. In Lecture Notes in Computer Science (including subseries Lecture Notes in Artificial Intelligence and Lecture Notes in Bioinformatics) (Vol. 8118 LNCS, pp. 118). https://doi.org/10.1007/978-3-642-40480-1_1

Iftanti, E., \& Shofiya, A. (2018). EFL Students' Responses on The Implementation of Extensive Reading Program to Build Love of Reading in English. Jurnal Bahasa Lingua Scientia, 1o(1). https://doi.org/10.21274/ls.2018.10.1.143-158

Johnsson-Smaragdi, U., \& Jönsson, A. (2006). Book reading in leisure time: Long-term changes in young peoples' book reading habits. Scandinavian Journal of Educational Research, 5O(5), 519-540. https://doi.org/10.1080/o0313830600953600

Larson, L. C. (2012). It's time to turn the digital page: Preservice teachers e xplore e-book reading. Journal of Adolescent and Adult Literacy, 56(4), 280-290. https://doi.org/10.1002/JAAL.00141

Loh, C. E., \& Sun, B. (2019). "I'd Still Prefer to Read the Hard Copy": Adolescents' Print and Digital Reading Habits. Journal of Adolescent and Adult Literacy, 62(6), 663-672. https://doi.org/10.1002/jaal.904

Manurung, K. (2015). Improving the Speaking Skill Using Reading Contextual Internet-based Instructional Materials in an EFL Class in Indonesia. Procedia - Social and Behavioral Sciences, 176, 44-51. https://doi.org/10.1016/J.SBSPRO.2015.01.442

Miles, M. B., \& Huberman, A. M. (1994). Qualitative Data Analysis; An Expanded Sourcebook. New Delhi: Sage Publication.

Pop, M.-C. (2015). Course Material Design Using the New Technologies in Language for Specific Purposes Teaching and Learning. Procedia - Social and Behavioral Sciences, 182, 325-330. https://doi.org/10.1016/J.SBSPRO.2015.04.774

Purwaningrum, A. Y., \& Yusuf, F. N. (2020). Investigating digitized authentic materials: Pre-service teachers voice. EduLite: Journal of English Education, Literature and Culture, 5(2), 225. https://doi.org/10.30659/e.5.2.225-239

Shariman, T. P. N. T., Razak, N. A., \& Noor, N. F. M. (2012). Digital Literacy Competence for Academic Needs: An Analysis of Malaysian Students in Three Universities. Procedia - Social and Behavioral Sciences, 69, 1489-1496. https://doi.org/10.1016/j.sbspro.2012.12.090

Sun, B., Loh, C. E., \& Nie, Y. (2021). The COVID-19 school closure effect on students' print and digital leisure reading. Computers and Education Open, 2, 100033. https://doi.org/10.1016/j.caeo.2021.100033

Szymkowiak, A., Melović, B., Dabić, M., Jeganathan, K., \& Kundi, G. S. (2021). Information technology and Gen Z: The role of teachers, the internet, and technology in the education of $\begin{array}{lllll}\text { young } & \text { people. } & & \end{array}$ https://doi.org/10.1016/j.techsoc.2021.101565

Tomlinson, B. (2013). Developing Materials For Language Teaching second edition. New York: Bloomsbury.

Uerz, D., Volman, M., \& Kral, M. (2018, February 1). Teacher educators' competences in fostering student teachers' proficiency in teaching and learning with technology: An overview of relevant research literature. Teaching and Teacher Education. Elsevier Ltd. https://doi.org/10.1016/j.tate.2017.11.005

Wahyuningsih, S. K. (2018). Developing Extensive Reading Material For Semester 2 Students Of Yogyakarta University Of Technology. Jurnal As-Salam, 2(3), 118-122. https://doi.org/10.37249/as-salam.v2i3.107 